\title{
The effect of energy-protein supplementation on weight, body composition and handgrip strength among pulmonary tuberculosis HIV-co-infected patients: randomised controlled trial in Mwanza, Tanzania
}

\author{
George PrayGod $^{1 *}$, Nyagosya Range ${ }^{2}$, Daniel Faurholt-Jepsen ${ }^{3}$, Kidola Jeremiah $^{1}$, \\ Maria Faurholt-Jepsen ${ }^{3}$, Martine G. Aabye ${ }^{4,5}$, Lotte Jensen ${ }^{4}$, Andreas V. Jensen ${ }^{4}$, \\ Harleen M. S. Grewal ${ }^{6}$, Pascal Magnussen ${ }^{7}$, John Changalucha ${ }^{1}$, Aase Bengaard Andersen ${ }^{4,8}$ \\ and Henrik Friis ${ }^{3}$ \\ ${ }^{1}$ National Institute for Medical Research, Mwanza Centre, Box 1462, Mwanza, Tanzania \\ ${ }^{2}$ National Institute for Medical Research, Mubimbili Centre, Tanzania \\ ${ }^{3}$ Department of Human Nutrition, Faculty of Life Sciences, University of Copenhagen, Denmark \\ ${ }^{4}$ Department of Infectious Diseases, Rigshospitalet, University of Copenhagen, Denmark \\ ${ }^{5}$ Clinical Research Centre, University of Copenhagen, Hvidoure Hospital, Denmark \\ ${ }^{6}$ The Gade Institute, Section for Microbiology and Immunology, University of Bergen and Department of Microbiology and \\ Immunology, Haukeland University Hospital, Norway \\ ${ }^{7}$ DBL-Centre for Health Research and Development, Department of Veterinary Disease Biology, Faculty of Life Sciences, \\ University of Copenhagen, Denmark \\ ${ }^{8}$ Department of Infections Diseases, Odense University Hospital, Denmark
}

(Received 23 August 2010 - Revised 16 February 2011 - Accepted 19 April 2011 - First published online 6 July 2011)

\section{Abstract}

Undernutrition is common among smear-positive pulmonary tuberculosis (PTB + ) patients. Micronutrient supplementation may improve treatment outcomes, but it is unclear whether additional energy-protein would be beneficial. The present study aimed to assess the effect of energy-protein supplementation on weight, body composition and handgrip strength against a background of high micronutrient intake during tuberculosis (TB) treatment. A total of 377 PTB + patients co-infected with HIV were randomly allocated one or six biscuits daily for $60 \mathrm{~d}$ during TB treatment. Weight, arm fat area, arm muscle area and handgrip strength were assessed at baseline and 2 and 5 months. There were no effects on any outcome at 2 months, but energy-protein supplementation was associated with a $1 \cdot 3$ ( $95 \%$ CI $-0 \cdot 1,2 \cdot 8) \mathrm{kg}$ marginally significant gain in handgrip strength at 5 months. However, after 2 months, energy-protein supplementation led to a weight gain of $1.9(95 \%$ CI $0 \cdot 1,3.7) \mathrm{kg}$ among patients with cluster of differentiation 4 (CD4) counts $\geq 350$ cells/ $\mu$ l, but not among patients with low CD4 counts $\left(-0.2 \mathrm{~kg} ; 95 \% \mathrm{CI}-1 \cdot 3,0 \cdot 8, P_{\text {interaction }}=0 \cdot 03\right)$. Similarly, at 5 months, energy-protein supplementation led to a $2 \cdot 3(95 \%$ CI $0 \cdot 6,4 \cdot 1) \mathrm{kg}$ higher handgrip strength gain among patients with CD4 counts $<350$ cells $/ \mu l$, but not in those with high CD 4 counts $\left(P_{\text {interaction }}=0 \cdot 04\right)$. In conclusion, energy-protein supplementation to PTB + HIV-co-infected patients had no overall effects on weight and body composition, but was associated with marginally significant gain in handgrip strength. More research is needed to develop an effective supplement, before it is recommended to TB programmes.

\section{Key words: Energy-protein supplementation: Pulmonary tuberculosis: HIV: Clinical trials}

Tuberculosis (TB) remains a major global health problem, with 9.4 million new cases and 1.7 million deaths each year ${ }^{(1)}$. HIV infection increases the risk of reactivation of latent $\mathrm{TB}^{(2)}$ and in settings where HIV prevalence is high; HIV co-infection may be above $50 \%$ in $\mathrm{TB}$ patients ${ }^{(3,4)}$.

Both TB and HIV cause undernutrition due to reduced food intake and increased utilisation of energy and nutrients ${ }^{(5-7)}$ and the co-existence of the two diseases may lead to more undernutrition ${ }^{(8-10)}$. Despite advances in HIV and TB management, undernutrition is common among HIV-infected TB patients ${ }^{(11)}$ and may affect treatment outcome and survival ${ }^{(12)}$ and regain of functional abilities. Thus, nutritional support should be an integrated component of case management, although there are insufficient data on the optimal nutrient amounts and composition ${ }^{(13)}$.

Abbreviations: ART, antiretroviral therapy; CD4, cluster of differentiation 4; NTLP, National TB and Leprosy Programme; PTB, pulmonary tuberculosis; TB, tuberculosis.

*Corresponding author: Dr G. PrayGod, fax +25528 2500654, email gpraygod@yahoo.com 
In a recent two-by-two factorial trial among sputum-positive pulmonary tuberculosis $(\mathrm{PTB}+)$ patients in Tanzania, we found that daily supplementation with $\mathrm{Zn}$ and other micronutrients increased weight gain by $2.4 \mathrm{~kg}$ and reduced mortality by $70 \%$ among those co-infected with $\mathrm{HIV}^{(12)}$. Based on these findings, we conducted two trials to further examine the effects of nutritional support on weight, body composition and handgrip strength. Among $\mathrm{PTB}+/ \mathrm{HIV}+$ patients, we assessed the effects of adding energy-protein to the multi-micronutrient supplement previously found to improve survival $^{(12)}$, whereas among PTB $+/ \mathrm{HIV}-, \mathrm{PTB}-/ \mathrm{HIV}+$ and PTB $-/ \mathrm{HIV}$ - patients, the effects of multi-micronutrient supplementation were assessed ${ }^{(14)}$. Here, we report the results of the first trial.

\section{Subjects and methods}

\section{Study setting and recruitment}

The study was conducted from April 2006 to March 2009 at four TB clinics in Mwanza city, under the Tanzanian National TB and Leprosy Programme (NTLP). Although the incidence of $\mathrm{TB}$ is still high in Tanzania (183 per 100000 population in 2009), the cure rate is $84 \%^{(1)}$, and the prevalence of multi-drug resistance TB is only $1.1 \%$ among new cases and $3.9 \%$ among relapse cases ${ }^{(15)}$.

New or relapse ${ }^{(16)}$ PTB + HIV-co-infected patients were enrolled in the study after giving a written informed consent if they were residents of Mwanza city. Patients with extrapulmonary $\mathrm{TB}$, pregnancy, age under 15 years or terminal illness were excluded. Patients who were either PTB - or $\mathrm{HIV}$ - were included in a concurrent trial ${ }^{(14)}$.

The diagnosis and treatment of TB followed established guidelines $^{(17)}$. Briefly, all TB suspects were asked to bring three sputum samples for sputum microscopy and were asked to do a chest X-ray as appropriate ${ }^{(17,18)}$. Patients were classified as PTB + , if two samples tested positive or one sample tested positive and a chest X-ray was suggestive of TB. After diagnosis, all patients were started on TB treatment based on existing national guidelines ${ }^{(16)}$. However, the treatment duration and mode of supervision for patients diagnosed with TB for the first time changed 6 months after the study started $^{(19)}$. From April 2006 to the end of September 2006, the total TB treatment period was 8 months using single drug tablets. Rifampicin, isoniazid, pyrazinamide and ethambutol were used in the first 2 months (intensive phase) and ethambutol and isoniazid for the last 6 months (continuation phase). Patients were observed daily for the intake of drugs at the health facility by a health worker during the intensive phase. During the continuation phase, patients collected drugs from the health facility on a monthly basis for selfadministration at their homes. From 1 October 2006, the NTLP reduced treatment duration from 8 to 6 months and introduced new drug formulations and mode of supervision. During this period, the same regimen consisting of rifampicin, isoniazid, pyrazinamide and ethambutol in a multi-drug tablet was used during the intensive phase and rifampicin and isoniazid were used during the continuation phase ( 4 months).
Patients were asked to choose either to have their treatment supervised at home or at the health facility. Those who chose home-based supervision had to select a person to supervise their daily treatment at home. Also, they had to collect drugs from the health facility once weekly during the intensive phase and every 2 weeks during the continuation phase. Those who chose health facility-based supervision had to take the drugs daily at the clinic throughout the treatment period. In both time periods, patients who were being re-treated for $\mathrm{TB}$, received treatment for 8 months and their drug intake was observed daily at the health facility ${ }^{(17)}$.

The management of HIV infection was done based on national guidelines at the time of the study ${ }^{(20)}$. Patients were immediately initiated on antiretroviral therapy (ART) if they had a cluster of differentiation 4 (CD 4 ) count of $<200$ cells $/ \mu l$, those with a WHO stage 4 illness and/or a CD 4 count of 200-350 cells/ $\mu$ l were initiated on ART after completion of 2 months of TB treatment, and the need for ART was assessed after completion of TB treatment for patients with a CD4 count of $>350$ cells/ $\mu$ l. Patients who developed TB after starting ART were allowed to continue with ART throughout TB treatment.

\section{Study design and interventions}

The study was a randomised controlled trial assessing the effect of energy-protein supplementation among HIVinfected $\mathrm{PTB}+$ patients on weight, arm fat area, arm muscle area and handgrip strength. Patients were randomised to receive one or six energy-protein biscuit bars daily for $60 \mathrm{~d}$ during the first 2 months of TB treatment. One of the biscuit bars given to the experimental group and the one given to the control group contained additional micronutrients, so that the supplemental micronutrient intake was similar in the two groups. Each energy-protein biscuit bar weighed $30 \mathrm{~g}$ and contained $4.5 \mathrm{~g}$ protein, $615 \mathrm{~kJ}$ energy, and $120 \mathrm{mg} \mathrm{P}$, $120 \mathrm{mg} \mathrm{Ca}, 36 \mathrm{mg} \mathrm{Mg}, 70 \mathrm{mg} \mathrm{Na}, 150 \mathrm{mg} \mathrm{K}$ and only traces $(<1 \mathrm{mg})$ of $\mathrm{Fe}$ and $\mathrm{Zn}$. The biscuit bar with additional micronutrients also contained the following: vitamin A $1.5 \mathrm{mg}$, vitamin $\mathrm{B}_{1} 20 \mathrm{mg}$, vitamin $\mathrm{B}_{2} 20 \mathrm{mg}$, vitamin $\mathrm{B}_{6} 25 \mathrm{mg}$, vitamin $\mathrm{B}_{12} 50 \mu \mathrm{g}$, folic acid $0.8 \mathrm{mg}$, niacin $40 \mathrm{mg}$, vitamin C $200 \mathrm{mg}$, vitamin E $60 \mathrm{mg}$, vitamin $\mathrm{D}_{3} 5 \mu \mathrm{g}$, Se $0.2 \mathrm{mg}, \mathrm{Cu} 5 \mathrm{mg}$ and $\mathrm{Zn}$ $30 \mathrm{mg}$. The amount of additional micronutrients was similar to what was found beneficial among TB patients previously ${ }^{(12)}$. The products were manufactured by Compact AS (Bergen, Norway) for the present trial, based on modification of a commercial product as requested by the researchers. Thus, each day, patients in the intervention arm received a total of $3690 \mathrm{~kJ}$ and $27 \mathrm{~g}$ protein, whereas those in the control arm received $615 \mathrm{~kJ}$ and $4.5 \mathrm{~g}$ protein. As a result, the trial tested the effect of providing about $50 \%$ of the daily energy requirement, and of the RDA for protein $^{(21)}$ based on an average of $60 \mathrm{~kg}$ weight for non-TB controls in this setting ${ }^{(22)}$. The levels of micronutrients in the two arms were similar, although the levels for $\mathrm{P}, \mathrm{Ca}$ and $\mathrm{Mg}$ were slightly higher in the intervention arm.

In order to match the mode of TB drug intake and supervision, in the first 6 months of the study, all supplements were 
taken under the observation of clinic staff, whereas from 1 October 2006 to the end of the study, most patients (90\%) took their supplements at home under the supervision of a home-based supporter, since they had also chosen to take their TB drugs at home. In this period, patients were advised against sharing the supplements with any family member and were asked to come to the TB clinic to collect their supplements every $6-12 \mathrm{~d}$. The remaining $10 \%$ of patients continued with health facility-based supplement intake supervision.

\section{Randomisation and allocation concealment}

Patients were allocated to treatment arms following a computer-generated randomisation sequence, using permuted blocks of ten. The sequence was generated using the website http:// www.randomization.com, and used by a designated research staff to sequentially arrange and label supplement packs with identity numbers ranging from 1 to 500. During the study, the randomisation sequence and code were kept in a safe cabinet and was only accessible to the designated research staff. Recruitment was done by TB clinic staff. Then, the same designated research staff who was not employed at any of the TB clinics assigned an identity number to the recruited patient, and sent the corresponding nutritional supplement pack to the respective clinic. Thereafter, TB clinic staff were responsible for dispensing the supplements and keeping the intake records. The present trial was not blinded since both patients and TB clinic staff could discern the experimental intervention.

\section{Outcome measures}

The primary outcomes were weight gain at 2 and 5 months, i.e. at the end of the supplementation period and 3 months after. Secondary outcomes were gains in arm fat area, arm muscle area and handgrip strength at 2 and 5 months.

\section{Data collection}

Data on demography, smoking and alcohol intake were collected using questionnaires while data on ART were retrieved from antiretroviral use databases in ART clinics. Between 08.00 and 12.00 hours, blood was collected in a $10 \mathrm{ml}$ plain vacutainer tube for HIV testing and a $5 \mathrm{ml}$ EDTA vacutainer tube for CD4 count. HIV status was determined using Capillus HIV-1/HIV-2 (Trinity Biotech Plc., Wicklow, Ireland) and Determine HIV-1/HIV-2 (Inverness Medical Innovations, Inc., Newark, DE, USA) tests in parallel. HIV infection was diagnosed if both tests gave a positive result and HIV-negative diagnosis was made if both tests produced a negative result. Indeterminate results were resolved using ELISA-Organon Uniform II (Organon Teknia Limited, Boxtel, The Netherlands). CD 4 count was determined as cells/ $\mu$ l using a Partec Cyflow Counter (Partec GmbH, Münster, German).

Weight was determined to the nearest $0 \cdot 1 \mathrm{~kg}$ using a digital scale (Seca, Australia) and height was determined to the nearest $0 \cdot 1 \mathrm{~cm}$ using a height board. Mid-upper arm circumference was determined to the nearest $0 \cdot 1 \mathrm{~cm}$ using a tape measure, and triceps skinfold thickness was determined to the nearest $0 \cdot 1 \mathrm{~mm}$ using the Harpenden caliper on the left arm. Measurements were made in duplicate, and are reported as mean values. Based on mid-upper arm circumference and triceps skinfold thickness measurements, arm muscle area and arm fat area were calculated as described previously ${ }^{(23)}$ and BMI was calculated as weight $(\mathrm{kg}) /(\text { height }(\mathrm{m}))^{2}$. Handgrip strength was determined to the nearest $0 \cdot 1 \mathrm{~kg}$ using a digital dynamometer (Takei Scientific Instruments Company Limited, Tokyo, Japan). A total of four measurements were taken, with the mean of the two maximum measurements (one in each hand) reported. All measurements were done at recruitment and repeated at the end of 2 and 5 months. Training was provided before the study, and regular supervision was done to ensure adherence of the protocol and the same staff did the measurements throughout the study.

\section{Ascertainment of supplement intake}

Before October 2006, TB clinic staff recorded directly the intake of supplements after patients had taken the supplement under their supervision. From October 2006 onwards, patients who chose to take supplements at home were asked to record the intake of supplements using a log designed for this purpose. When patients came to collect another pack of nutritional supplements, the log was handed to the TB clinic for updating the supplement intake record. Intake of at least $80 \%$ of the supplements was regarded as adequate compliance.

\section{Sample size and power considerations}

We planned to recruit 500 PTB patients. In a previous trial, we found that the standard deviation for weight gain in the first 2 months was $3.5 \mathrm{~kg}$ (N Range, AB Andersen, A Mugomela and H Früs). Therefore, we would be able to detect a $0.95 \mathrm{~kg}$ or a greater weight-gain difference with $80 \%$ power and 5\% significance level, while allowing for $15 \%$ loss to follow-up. With recruitment of 377 patients and a $12 \%$ loss to follow-up, we would be able to detect an overall $1 \cdot 1 \mathrm{~kg}$ weight-gain difference between the two groups.

\section{Statistical analysis}

Data were twice entered in EpiData (EpiData Association, Odense, Denmark) and analysed using Stata/IC version 10 (StataCorp LP, College Station, TX, USA). Normal probability plots were used to assess normality of the continuous variables. Differences in categorical and continuous variables between groups were tested using the $\chi^{2}$ test and $t$ test, respectively. Additionally, linear regression was used to adjust for potential confounders and to test for interactions with respect to baseline CD4 count groups $(<350$ or $\geq 350$ cells $/ \mu \mathrm{l}$ ), sex, ART during supplementation and mode of supplementation (clinic- $v$. home-based supplementation). Where interaction was detected, the effect of the intervention was assessed by the level of the effect modifier. Analysis was done on an intention-to-treat basis. $P$ values below 0.05 were 
considered significant. The trial was registered at ClinicalTrials.gov (http://clinicaltrials.gov) identifier: NCT00311298.

\section{Ethical considerations}

The present study was conducted according to the guidelines laid down in the Declaration of Helsinki. Written informed consent was obtained from all patients enrolled in the present study. Ethical permission was obtained from the National Medical Research Coordinating Committee of the National Institute of Medical Research in Tanzania and approval from the Danish National Committee on Biomedical Research Ethics. Patients who did not know their HIV status were offered pre- and post-test HIV counselling and referred to nearby ART clinics for management.

\section{Results}

Of the $1042 \mathrm{~TB}$ patients who were screened at TB clinics during the recruitment period, 398 (38.2\%) were eligible, of which $377(94.7 \%)$ consented to participate in the trial. As seen in the trial profile (Fig. 1), of those not eligible, $154(23.9 \%)$ had extra-pulmonary TB, 376 (58.4\%) were non-residents and the remaining 114 (17.7\%) were aged $<15$ years, terminally ill or pregnant. Of the 377 recruited, the mean age was 35.4 (range 16-80) years, BMI was 18.6 (SD 2.9$) \mathrm{kg} / \mathrm{m}^{2}$, and $187(49.6 \%)$ were females and 261 (69.4\%) had CD 4 cell counts below 350 cells/ $\mu$ l. Baseline CD 4 count data for one patient in the energy-protein group were not available.
Randomisation achieved baseline equivalence of background characteristics (Table 1). At 2 and 5 months, forty-six $(12 \cdot 2 \%)$ and seventy-two $(19 \cdot 1 \%)$ patients were lost to follow-up, respectively. However, at both time points, the proportions lost to follow-up were similar across intervention and control arms (13.2 v. 11.2\%; $P=0.54$ and 19.6 v. $18.6 \%$; $P=0.81$, respectively). At 2 months, those lost to follow-up had lower arm muscle area $\left(29.6\right.$ v. $\left.33.8 \mathrm{~cm}^{2} ; P=0.03\right)$, whereas those lost at 5 months had lower weight (48.5 v. $51.5 \mathrm{~kg} ; P=0.01)$ and arm muscle area $\left(30.4 \mathrm{v} .34 .0 \mathrm{~cm}^{2}\right.$; $P=<0 \cdot 001)$. The proportion of patients on ART kept on increasing after study entry, but this proportion did not differ between intervention and control arms at 2 and 5 months (25.9 v. 21.3\%; $P=0.29$ and 33.3 v. 32.5\%; $P=0.86$, respectively). In addition, throughout the follow-up period, the group with CD4 counts $<350$ cells/ $\mu$ l had a larger proportion of patients on ART (Table 2).

Overall, study patients had considerable weight and handgrip strength gain by the end of 2 and 5 months of treatment. However, energy-protein supplementation had no main effects on gain in weight, arm fat and muscle area, and handgrip strength at 2 and 5 months, but was associated with a marginally significantly higher increase in handgrip strength (1.3kg; 95\% CI $-0.1,2 \cdot 8 ; P=0.07$ ) at 5 months (Table 3 ). At 2 months, there was an interaction between energyprotein supplementation and CD4 count level for weight $\left(P_{\text {interaction }}=0.03\right)$, which was explained by a $1.9 \mathrm{~kg}(95 \% \mathrm{CI}$ $0 \cdot 1,3 \cdot 7 ; P=0.04)$ higher weight gain among patients with CD 4 counts of 350 cells/ $\mu$ l or higher, and the lack of effect among those who had CD 4 counts below 350 cells $/ \mu 1$ $(-0.2 \mathrm{~kg} ; 95 \% \mathrm{CI}-1.3,0.8 ; P=0.66)$. The beneficial effect

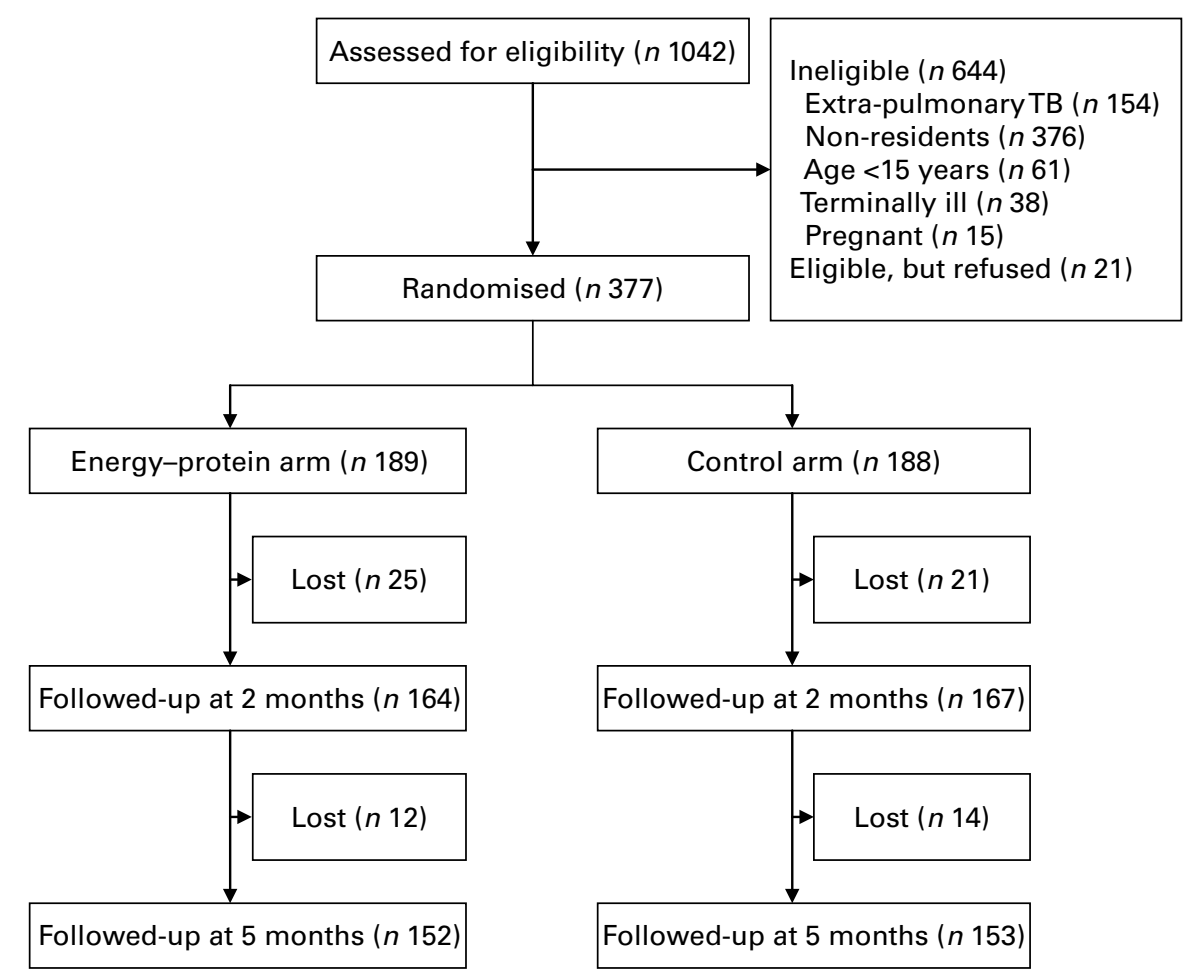

Fig. 1. Trial flow chart. TB, tuberculosis. 
Table 1. Baseline characteristics of 377 pulmonary tuberculosis patients randomised to either the energy-protein or control group (Percentages, number of patients, mean values and standard deviations)

\begin{tabular}{|c|c|c|c|c|c|c|c|c|}
\hline & \multicolumn{4}{|c|}{ Energy-protein group ( $n$ 189) } & \multicolumn{4}{|c|}{ Control group ( $n$ 188) } \\
\hline & Prevalence (\%) & $n$ & Mean & SD & Prevalence (\%) & $n$ & Mean & SD \\
\hline Age (years) & & & 34.7 & $10 \cdot 3$ & & & $36 \cdot 2$ & 9.5 \\
\hline Female sex & 50 & 94 & & & 49 & 93 & & \\
\hline $\operatorname{BMI}\left(\mathrm{kg} / \mathrm{m}^{2}\right)$ & & & $18 \cdot 7$ & $2 \cdot 9$ & & & $18 \cdot 5$ & $2 \cdot 8$ \\
\hline \multicolumn{9}{|l|}{ BMI $\left(\mathrm{kg} / \mathrm{m}^{2}\right)$ groups } \\
\hline$<16$ & 14.9 & 28 & & & $13 \cdot 3$ & 25 & & \\
\hline $16-16 \cdot 9$ & 14.4 & 27 & & & $15 \cdot 4$ & 29 & & \\
\hline $17-18.49$ & $22 \cdot 3$ & 42 & & & $27 \cdot 7$ & 52 & & \\
\hline$\geq 18.5$ & 48.4 & 91 & & & $43 \cdot 6$ & 82 & & \\
\hline \multicolumn{9}{|l|}{ Ethnicity } \\
\hline Wasukuma & 52 & 98 & & & 52 & 97 & & \\
\hline Others & 48 & 91 & & & 48 & 91 & & \\
\hline \multicolumn{9}{|l|}{ Marital status } \\
\hline Single & 25 & 47 & & & 22 & 41 & & \\
\hline Married/co-habiting & 49 & 91 & & & 51 & 95 & & \\
\hline Separated/divorced/widowed & 26 & 49 & & & 27 & 50 & & \\
\hline \multicolumn{9}{|l|}{ Occupation } \\
\hline Farming/fishing & 40.4 & 76 & & & $43 \cdot 3$ & 81 & & \\
\hline Business/employed & $34 \cdot 1$ & 64 & & & $35 \cdot 8$ & 67 & & \\
\hline Housewife & $12 \cdot 2$ & 23 & & & $12 \cdot 3$ & 23 & & \\
\hline Unemployed & $13 \cdot 3$ & 25 & & & 8.6 & 16 & & \\
\hline \multicolumn{9}{|l|}{ Smoking } \\
\hline Never & 73 & 138 & & & 74 & 139 & & \\
\hline Past & 12 & 23 & & & 9 & 17 & & \\
\hline Current & 15 & 28 & & & 17 & 32 & & \\
\hline Alcohol drinking & 41 & 77 & & & 46 & 87 & & \\
\hline \multicolumn{9}{|l|}{ CD4 count (cells/ $\mu$ l) groups } \\
\hline$<50$ & 3.7 & 7 & & & 3.7 & 7 & & \\
\hline $50-199$ & $37 \cdot 2$ & 70 & & & $36 \cdot 2$ & 68 & & \\
\hline $200-349$ & $27 \cdot 2$ & 51 & & & $30 \cdot 8$ & 58 & & \\
\hline$\geq 350$ & 31.9 & 60 & & & $29 \cdot 3$ & 55 & & \\
\hline ART prior randomisation & 16 & 30 & & & 11 & 21 & & \\
\hline
\end{tabular}

CD4, cluster of differentiation 4; ART, antiretroviral therapy.

seemed to be accompanied by changes in both arm fat and muscle area, though the estimates were not significant (Table 4). After 5 months, there was an interaction between energy-protein supplementation and CD4 count level for handgrip strength $\left(P_{\text {interaction }}=0.04\right)$, which was explained by a $2 \cdot 3 \mathrm{~kg}(95 \% \mathrm{CI} 0 \cdot 6,4 \cdot 1 ; P=0 \cdot 009)$ higher gain in handgrip strength among those with CD4 counts of $<350$ cells $/ \mu l$ and lack of effect among those with higher CD4 counts $(-1.0 \mathrm{~kg} ; 95 \% \mathrm{CI}-3.5,1.5 ; P=0.43$; Table 4). Interestingly, at 5 months, there was a marginally significant interaction between energy-protein supplementation and ART use for handgrip strength $\left(P_{\text {interaction }}=0.08\right)$ due to a greater effect of energy-protein supplementation on handgrip strength among those on ART $(3.0 \mathrm{~kg} ; 95 \%$ CI $0.5,5.6 ; P=0.02)$ but not among those not on ART $(0.4 \mathrm{~kg} ; 95 \% \mathrm{CI}-1 \cdot 3$, $1.5 ; P=0.61$.

Proportions of patients with adequate compliance did not differ between the period when supplements were taken in clinics compared with when they were taken mainly at home $(90.6 v .87 .4 \% ; P=0.47)$. Similarly, in both periods, the proportions of patients with adequate compliance did not differ between the study arms $(P=0.34$ and $P=0.66$, respectively). Furthermore, the effect of the intervention on weight at 2 months was not modified by compliance
$\left(P_{\text {interaction }}=0.52\right)$. There was no confounding or effect modification by sex and mode of supplementation.

\section{Discussion}

The present study was based on the results of our earlier twoby-two factorial trial in which PTB + patients were randomised to either multi-micronutrients (excluding $\mathrm{Zn}$ ) or placebo, and independently to $\mathrm{Zn}$ or placebo, to be taken daily alongside TB treatment for 8 months ${ }^{(12)}$. In this earlier trial, we found that by the end of the 7th month of supplementation, there was an interaction between $\mathrm{Zn}$ and other micronutrients,

Table 2. Antiretroviral use among 376 pulmonary tuberculosis patients at baseline and during a 5-month follow-up period

(Number of patients and percentages)

\begin{tabular}{|c|c|c|c|c|c|c|c|}
\hline \multirow{2}{*}{ 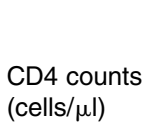 } & \multirow{2}{*}{$\begin{array}{c}\text { Total } \\
(n)\end{array}$} & \multicolumn{2}{|c|}{ At baseline } & \multicolumn{2}{|c|}{$\begin{array}{c}\text { At } \\
2 \text { months }\end{array}$} & \multicolumn{2}{|c|}{$\begin{array}{c}\text { At } \\
5 \text { months }\end{array}$} \\
\hline & & $n$ & $\%$ & $n$ & $\%$ & $n$ & $\%$ \\
\hline$<350$ & 261 & 38 & 14.6 & 74 & 28.4 & 103 & 39.5 \\
\hline$\geq 350$ & 115 & 13 & 11.3 & 15 & $13 \cdot 0$ & 21 & $18 \cdot 3$ \\
\hline
\end{tabular}

CD4, cluster of differentiation 4. 
Table 3. Effect of energy-protein supplementation on weight, arm fat area, arm muscle area and handgrip strength among 377 pulmonary tuberculosis patients at 2 and 5 months (Number of patients, mean values and $95 \%$ confidence intervals)

\begin{tabular}{|c|c|c|c|c|c|c|c|}
\hline & \multicolumn{3}{|c|}{ Energy-protein group ( $n$ 189) } & \multicolumn{3}{|c|}{ Control group ( $n$ 188) } & \multirow[b]{2}{*}{$P^{*}$} \\
\hline & $n$ & Mean & $95 \% \mathrm{Cl}$ & $n$ & Mean & $95 \% \mathrm{Cl}$ & \\
\hline \multicolumn{8}{|l|}{ Weight (kg) } \\
\hline Baseline & 189 & $50 \cdot 9$ & $49 \cdot 6,52 \cdot 1$ & 188 & $50 \cdot 9$ & $49 \cdot 7,52 \cdot 2$ & \\
\hline 2 months & 166 & $54 \cdot 0$ & $52 \cdot 5,55 \cdot 6$ & 166 & 53.7 & $52 \cdot 2,55 \cdot 1$ & \\
\hline Change† & 166 & 2.9 & $2 \cdot 3,3 \cdot 5$ & 166 & 2.5 & $1 \cdot 8,3 \cdot 1$ & \\
\hline Difference & & 0.4 & $-0.5,1.4$ & & & & 0.33 \\
\hline 5 months & 151 & $57 \cdot 3$ & $55 \cdot 8,58 \cdot 8$ & 155 & $57 \cdot 8$ & $56 \cdot 2,59 \cdot 4$ & \\
\hline Change† & 151 & $6 \cdot 0$ & $5 \cdot 2,6 \cdot 7$ & 155 & $6 \cdot 2$ & $5 \cdot 2,7 \cdot 1$ & \\
\hline Difference $\ddagger$ & & -0.2 & $-1 \cdot 4,1 \cdot 0$ & & & & 0.75 \\
\hline \multicolumn{8}{|c|}{ Arm fat area $\left(\mathrm{cm}^{2}\right)$} \\
\hline Baseline & 188 & $8 \cdot 0$ & $7 \cdot 3,8 \cdot 7$ & 186 & $7 \cdot 8$ & $7 \cdot 0,8 \cdot 5$ & \\
\hline 2 months & 165 & $9 \cdot 2$ & $8.4,9.9$ & 168 & $9 \cdot 2$ & $8 \cdot 3,10 \cdot 2$ & \\
\hline Change† & 164 & $1 \cdot 0$ & $0.4,1.5$ & 167 & $1 \cdot 3$ & $0.9,1 \cdot 7$ & \\
\hline Difference $\ddagger$ & & -0.3 & $-1.0,0.3$ & & & & 0.32 \\
\hline 5 months & 151 & $11 \cdot 3$ & $10 \cdot 5,12 \cdot 2$ & 155 & $11 \cdot 2$ & $10 \cdot 1,12 \cdot 3$ & \\
\hline Change† & 150 & $3 \cdot 1$ & $2 \cdot 3,3 \cdot 8$ & 153 & $3 \cdot 3$ & $2 \cdot 6,4 \cdot 0$ & \\
\hline Differenceł & & -0.2 & $-1 \cdot 2,0.8$ & & & & 0.66 \\
\hline \multicolumn{8}{|c|}{ Arm muscle area $\left(\mathrm{cm}^{2}\right)$} \\
\hline Baseline & 188 & 33.8 & $32 \cdot 5,35 \cdot 0$ & 186 & $32 \cdot 8$ & $31 \cdot 5,34 \cdot 0$ & \\
\hline 2 months & 165 & $36 \cdot 8$ & $35 \cdot 2,38 \cdot 4$ & 168 & $35 \cdot 1$ & $33 \cdot 7,36 \cdot 5$ & \\
\hline Change $†$ & 164 & $2 \cdot 6$ & $1 \cdot 8,3.5$ & 166 & $2 \cdot 1$ & $1 \cdot 3,3 \cdot 0$ & \\
\hline Differenceł & & 0.50 & $-0 \cdot 7,1 \cdot 7$ & & & & 0.41 \\
\hline 5 months & 151 & $40 \cdot 4$ & $38.8,41.9$ & 155 & 39.9 & $38 \cdot 3,41 \cdot 4$ & \\
\hline Change† & 150 & 5.9 & $4 \cdot 9,7 \cdot 0$ & 153 & $6 \cdot 3$ & $5 \cdot 2,7 \cdot 4$ & \\
\hline Difference & & -0.4 & $-1 \cdot 9,1 \cdot 2$ & & & & 0.63 \\
\hline \multicolumn{8}{|c|}{ Handgrip strength $(\mathrm{kg})$} \\
\hline Baseline & 188 & $24 \cdot 1$ & $22 \cdot 9,25 \cdot 3$ & 187 & $24 \cdot 0$ & $22 \cdot 8,25 \cdot 2$ & \\
\hline 2 months & 166 & $26 \cdot 6$ & $25 \cdot 2,27 \cdot 9$ & 168 & $26 \cdot 5$ & $25 \cdot 1,27 \cdot 9$ & \\
\hline Change† & 165 & $2 \cdot 3$ & $1 \cdot 6,3 \cdot 1$ & 167 & $1 \cdot 8$ & $1 \cdot 1,2 \cdot 6$ & \\
\hline Difference $\ddagger$ & & 0.5 & $-0.6,1.5$ & & & & 0.37 \\
\hline 5 months & 151 & 30.4 & $29 \cdot 1,31 \cdot 8$ & 154 & $29 \cdot 7$ & $28 \cdot 2,31 \cdot 1$ & \\
\hline Change† & 150 & $6 \cdot 0$ & $5 \cdot 0,7 \cdot 0$ & 153 & $4 \cdot 7$ & $3 \cdot 6,5 \cdot 7$ & \\
\hline Difference & & $1 \cdot 3$ & $-0.1,2 \cdot 8$ & & & & 0.07 \\
\hline
\end{tabular}

in that patients receiving both $\mathrm{Zn}$ and other micronutrients had an additional weight gain of $2.4 \mathrm{~kg}$, and among those who were HIV-co-infected, there was a $70 \%$ reduction in mortality. Based on these results, we wanted to test whether supplementation with energy-protein in addition to micronutrients further improves weight and handgrip strength among $\mathrm{PTB}+\mathrm{HIV}$-Co-infected patients, and how it affected arm muscle or fat area.

In the present trial, we found no overall effects of the experimental intervention on weight and body composition, but an additional $1.3 \mathrm{~kg}$ increase in handgrip strength at 5 months, although this was only marginally significant. This finding is similar to that in the study in Singapore ${ }^{(24)}$. In the Singaporean study, investigators tested the effect of high-energy (including protein) supplementation $v$. dietary advice on weight and grip strength among TB patients for 6 weeks. They found that at 6 weeks, the intervention led to a considerable increase in grip strength. However, in contrast to our findings, the increase was associated with an increase in lean mass and was not sustained at 6 months. These discrepancies between the two studies may probably be explained by differences in study populations and designs. For example, the Singaporean study did not include HIV + patients, whereas all the present study participants were HIV-infected. Handgrip strength is a proxy measure of work capacity and therefore its increase among TB patients is important, because it may lead to improved ability to produce or procure foods, and hence patients may be able to better care their families.

Regarding the lack of overall effects, we see five possible explanations. First, compliance with respect to the supplement may have been inadequate, in that patients in the experimental arm may have not taken all the five additional biscuits or the biscuits may have replaced rather than supplemented the usual diet with $50 \%$ of the requirements for a healthy individual. Although our data suggest that compliance was very high; this explanation cannot be ruled out considering that most of the patients took the supplements at home and thus their compliance was reported rather than observed. Second, the present trial was not blinded, and thus data collectors knew which patients were receiving the experimental intervention, which may have resulted in information bias. However, this is unlikely since such a bias would more probably have caused beneficial effects, rather than eliminated a true effect. Third, the amount of protein and micronutrients 
Table 4. Effect of energy-protein supplementation on weight, arm fat area, arm muscle area and handgrip strength among 376 pulmonary tuberculosis patients at 2 and 5 months by cluster of differentiation 4 (CD4) count groups

(Number of patients, mean values and $95 \%$ confidence intervals)

\begin{tabular}{|c|c|c|c|c|c|c|c|c|c|c|c|c|c|c|c|}
\hline & \multicolumn{7}{|c|}{ Low CD4 count $(<350$ cells/ $/$ l) $(n 261)$} & \multicolumn{7}{|c|}{ High CD4 count ( $\geq 350$ cells/ $\mu$ l) $(n 115)$} & \multirow[b]{3}{*}{$P \dagger$} \\
\hline & \multicolumn{3}{|c|}{ Energy-protein group } & \multicolumn{3}{|c|}{ Control group } & \multirow[b]{2}{*}{$P^{*}$} & \multicolumn{3}{|c|}{ Energy-protein group } & \multicolumn{3}{|c|}{ Control group } & \multirow[b]{2}{*}{$P^{*}$} & \\
\hline & $n$ & Mean & $95 \% \mathrm{Cl}$ & $n$ & Mean & $95 \% \mathrm{Cl}$ & & $n$ & Mean & $95 \% \mathrm{Cl}$ & $n$ & Mean & $95 \% \mathrm{Cl}$ & & \\
\hline \multicolumn{16}{|l|}{ Weight (kg) } \\
\hline Baseline & 128 & $50 \cdot 2$ & $48 \cdot 7,51 \cdot 8$ & 138 & $50 \cdot 2$ & $48 \cdot 7,51 \cdot 7$ & & 60 & $52 \cdot 2$ & $49 \cdot 9,54 \cdot 5$ & 55 & $52 \cdot 8$ & $50 \cdot 7,54 \cdot 8$ & & \\
\hline 2 months & 111 & 53.0 & $51 \cdot 2,54 \cdot 8$ & 119 & $53 \cdot 0$ & $51 \cdot 1,54 \cdot 8$ & & 55 & $56 \cdot 2$ & $53 \cdot 4,59 \cdot 0$ & 47 & $55 \cdot 4$ & $55 \cdot 3,57 \cdot 4$ & & \\
\hline Change & 111 & $2 \cdot 4$ & $1 \cdot 7,3 \cdot 1$ & 119 & $2 \cdot 6$ & $1 \cdot 8,3 \cdot 4$ & & 55 & 4.0 & $2 \cdot 7,5 \cdot 3$ & 47 & $2 \cdot 1$ & $0.9,3.3$ & & \\
\hline Difference§ & & -0.2 & $-1 \cdot 3,0 \cdot 8$ & & & & 0.66 & & 1.9 & $0.1,3.7$ & & & & 0.04 & 0.03 \\
\hline 5 months & 105 & $56 \cdot 8$ & $55 \cdot 0,58 \cdot 5$ & 111 & $57 \cdot 2$ & $55 \cdot 1,59 \cdot 2$ & & 46 & $58 \cdot 6$ & $55 \cdot 9,61 \cdot 4$ & 44 & $59 \cdot 3$ & $57 \cdot 1,61 \cdot 6$ & & \\
\hline Change & 105 & $6 \cdot 0$ & $5 \cdot 0,6 \cdot 9$ & 111 & $6 \cdot 3$ & $5 \cdot 2,7 \cdot 4$ & & 46 & $6 \cdot 0$ & $4 \cdot 6,7 \cdot 3$ & 44 & 5.9 & $4 \cdot 2,7 \cdot 5$ & & \\
\hline Difference§ & & -0.3 & $-1 \cdot 8,1 \cdot 1$ & & & & 0.67 & & 0.1 & $-2 \cdot 0,2 \cdot 2$ & & & & 0.92 & 0.75 \\
\hline \multicolumn{16}{|c|}{ Arm fat area $\left(\mathrm{cm}^{2}\right)$} \\
\hline Baseline & 127 & $8 \cdot 0$ & $7 \cdot 1,8 \cdot 9$ & 131 & $7 \cdot 4$ & $6 \cdot 6,8 \cdot 3$ & & 60 & 8.0 & $6 \cdot 9,9 \cdot 1$ & 55 & 8.5 & $6 \cdot 9,10 \cdot 1$ & & \\
\hline 2 months & 110 & $9 \cdot 2$ & $8 \cdot 2,10 \cdot 1$ & 120 & $9 \cdot 0$ & $7 \cdot 9,10 \cdot 1$ & & 55 & $9 \cdot 2$ & $8 \cdot 0,10 \cdot 4$ & 48 & $9 \cdot 7$ & $7 \cdot 8,11 \cdot 7$ & & \\
\hline Changeł & 109 & 0.8 & $0.2,1.5$ & 118 & 1.4 & $0.9,1.9$ & & 55 & 1.3 & $0.4,2 \cdot 2$ & 48 & 1.1 & $0.3,1.9$ & & \\
\hline Difference§ & & -0.6 & $-1 \cdot 4,0.2$ & & & & 0.16 & & 0.2 & $-1 \cdot 0,1 \cdot 4$ & & & & 0.76 & 0.30 \\
\hline 5 months & 105 & 11.4 & $10 \cdot 4,12 \cdot 4$ & 111 & $11 \cdot 0$ & $9 \cdot 7,12 \cdot 2$ & & 46 & $11 \cdot 1$ & $9 \cdot 5,12 \cdot 7$ & 44 & $11 \cdot 7$ & $9 \cdot 4,13.9$ & & \\
\hline Changeł & 104 & 3.0 & $2 \cdot 1,3 \cdot 9$ & 109 & 3.4 & $2 \cdot 6,4 \cdot 3$ & & 46 & $3 \cdot 1$ & $1 \cdot 7,4.5$ & 44 & $2 \cdot 8$ & $1 \cdot 5,4 \cdot 1$ & & \\
\hline Difference§ & & -0.4 & $-1 \cdot 6,0.8$ & & & & 0.49 & & 0.3 & $-1 \cdot 6,2 \cdot 2$ & & & & 0.78 & 0.54 \\
\hline \multicolumn{16}{|c|}{ Arm muscle area $\left(\mathrm{cm}^{2}\right)$} \\
\hline Baseline & 127 & $33 \cdot 2$ & $31 \cdot 6,34 \cdot 7$ & 131 & $32 \cdot 2$ & $30 \cdot 7,33 \cdot 6$ & & 60 & 34.9 & $32 \cdot 6,37 \cdot 2$ & 55 & $34 \cdot 2$ & $31 \cdot 7,36 \cdot 6$ & & \\
\hline 2 months & 110 & $36 \cdot 3$ & $34 \cdot 3,38 \cdot 2$ & 120 & 33.9 & $32 \cdot 3,35 \cdot 6$ & & 55 & 37.9 & $35 \cdot 1,40 \cdot 8$ & 48 & 37.9 & $35.3,40.5$ & & \\
\hline Changeł & 109 & 2.5 & $1.4,3.7$ & 118 & 1.9 & $0.9,2.9$ & & 55 & $2 \cdot 9$ & $1 \cdot 7,4 \cdot 1$ & 48 & 2.6 & $0.8,4.5$ & & \\
\hline Difference§ & & 0.6 & $-0.9,2 \cdot 1$ & & & & 0.44 & & 0.3 & $-1 \cdot 9,2 \cdot 4$ & & & & 0.82 & 0.79 \\
\hline 5 months & 105 & 39.9 & $38 \cdot 0,41 \cdot 8$ & 111 & 38.9 & $37 \cdot 0,40 \cdot 7$ & & 46 & 41.4 & $38.5,44.4$ & 44 & $42 \cdot 4$ & $39 \cdot 5,45 \cdot 3$ & & \\
\hline Change $\ddagger$ & 104 & 5.9 & $4 \cdot 6,7 \cdot 2$ & 109 & $6 \cdot 0$ & $4 \cdot 6,7 \cdot 3$ & & 46 & $6 \cdot 1$ & $4 \cdot 1,8 \cdot 0$ & 44 & $7 \cdot 3$ & $5 \cdot 2,9 \cdot 3$ & & \\
\hline Difference§ & & -0.1 & $-1 \cdot 9,1 \cdot 8$ & & & & 0.97 & & $-1 \cdot 2$ & $-4 \cdot 0,1 \cdot 6$ & & & & 0.39 & 0.49 \\
\hline \multicolumn{16}{|c|}{ Handgrip strength $(\mathrm{kg})$} \\
\hline Baseline & 127 & $23 \cdot 1$ & $21 \cdot 6,24 \cdot 5$ & 133 & 23.5 & $22 \cdot 2,24 \cdot 9$ & & 60 & $26 \cdot 2$ & $24 \cdot 1,28 \cdot 3$ & 54 & $25 \cdot 2$ & $22 \cdot 7,27 \cdot 7$ & & \\
\hline 2 months & 111 & $26 \cdot 1$ & $24 \cdot 5,27 \cdot 7$ & 120 & $25 \cdot 8$ & $24 \cdot 2,27 \cdot 5$ & & 55 & $27 \cdot 5$ & $25 \cdot 2,29 \cdot 9$ & 48 & $28 \cdot 1$ & $25 \cdot 3,30 \cdot 8$ & & \\
\hline Change‡ & 110 & $2 \cdot 6$ & $1 \cdot 7,3 \cdot 6$ & 120 & 1.9 & $1 \cdot 0,2 \cdot 8$ & & 55 & $1 \cdot 7$ & $0.5,2 \cdot 8$ & 47 & 1.7 & $0 \cdot 3,3 \cdot 1$ & & \\
\hline Difference§ & & 0.7 & $-0.5,2.0$ & & & & 0.26 & & -0.005 & $-1 \cdot 8,1 \cdot 8$ & & & & 0.99 & 0.52 \\
\hline 5 months & 105 & 30 & $28 \cdot 4,31 \cdot 7$ & 110 & $28 \cdot 6$ & $26 \cdot 9,30 \cdot 3$ & & 46 & 31.4 & $28 \cdot 7,34 \cdot 0$ & 44 & $32 \cdot 4$ & $29 \cdot 6,35 \cdot 1$ & & \\
\hline Changeł & 104 & $6 \cdot 6$ & $5 \cdot 3,7 \cdot 8$ & 110 & $4 \cdot 3$ & $3 \cdot 0,5 \cdot 5$ & & 46 & $4 \cdot 8$ & $3 \cdot 1,6 \cdot 4$ & 43 & $5 \cdot 8$ & $3 \cdot 8,7 \cdot 7$ & & \\
\hline Difference§ & & $2 \cdot 3$ & $0.6,4 \cdot 1$ & & & & 0.009 & & $-1 \cdot 0$ & $-3.5,1.5$ & & & & 0.43 & 0.04 \\
\hline
\end{tabular}

*Difference assessed using the unpaired $t$ test.

†Test for interaction between energy-protein supplementation and CD4 count groups.

computed as the mean increase from baseline to follow-up.

$\S$ Difference computed as the mean change in energy-protein minus the control group. 
provided per day or the duration of supplementation may have been inadequate to support the accrual of new tissues. Since both TB and HIV infections are catabolic processes $^{(11,25,26)}$, the repletion of lean mass may require higher amounts of protein and other nutrients to compensate for the impairment in anabolism which is associated with infection $^{(27-29)}$. Furthermore, the amount of $\mathrm{Zn}$ and other type II nutrients such as $\mathrm{P}$ and $\mathrm{K}$ provided may have been inadequate to meet the demands for additional lean tissue synthesis posed by additional intake of energy-protein. This is plausible considering that $\mathrm{Zn}$ is essential in cell division and protein synthesis $^{(30)}$ and both $\mathrm{P}$ and $\mathrm{K}$ are important in anabolism ${ }^{(31)}$. Fourth, the supplement may have increased physical activity and hence energy requirements, rather than leading to increased weight gain. Although this is likely, as reflected in the marginally significant increase in handgrip strength, we cannot ascertain it since we did not have the means to assess energy balance. Fifth, inadequate disease treatment may have led to low supplement intake and/or increased energy expenditure. With respect to TB treatment, this is unlikely to explain the lack of effect since as reported, under the NTLP, the cure rate is high, prevalence of multidrug resistance $\mathrm{TB}$ is low and the proportion of patients who might have atypical mycobacterial infection, i.e. those with CD 4 counts $<50$ cells $/ \mu l^{(32)}$, was about $3 \%$. However, with regard to HIV treatment, the proportion of patients who were on ART was lower than expected at baseline and throughout the follow-up period. For example, at baseline, about $40 \%$ of all patients had CD 4 counts of $<200$ cells $/ \mu l$ and expected to be on ART, but only $13 \%$ were receiving antiretroviral drugs. Thus, it is likely that inadequate HIV management may have contributed to the lack of effect of the intervention probably due to recurrent opportunistic infections.

Among the subgroups defined by CD4 count level, we found the seemingly beneficial effect on weight at 2 months among patients with higher CD4 counts and on handgrip strength among those with lower CD 4 counts at 5 months. The differences in intervention effects at 2 months may probably be explained by a tendency to have a better nutrient intake and metabolism among those with higher CD4 counts compared with the general HIV-infected PTB + population and vice versa among those with lower CD 4 counts. Similarly, among the subgroups defined by ART use, we found that the intervention tended to have a beneficial effect on handgrip strength among patients who were on ART at 5 months. This may suggest that among PTB + HIV-infected patients, irrespective of CD4 counts, ART may enhance the increase in mass muscle and/or muscle function, which are the major determinants of handgrip strength, probably because ART may prevent against recurrent opportunistic infections, the main cause of weight and possibly functional loss among HIV-infected patients ${ }^{(33)}$. In fact, the beneficial effect of the intervention on handgrip strength at 5 months among patients who had CD 4 counts $<350$ cells $/ \mu$ at baseline may be explained by the fact that at this time, $40 \%$ of these patients were receiving ART compared with only $18 \%$ among those with CD4 count $\geq 350$ cells/ $\mu$ l.
At the end of 5 months, patients in both arms had gained considerable weight, although this was only about $60 \%$ of $7-10 \mathrm{~kg}$ of the deficits found at the beginning of TB treatment ${ }^{(22,34)}$. Although deficit in weight at the beginning of treatment is due to many factors including pre-TB underweight and HIV infection, most of the deficit is due to active $\mathrm{TB}^{(22)}$. Therefore, nutritional support against a background of TB treatment should ensure regaining of nearly all the deficit by the time treatment is completed. The suboptimal weight recovery, even among the sub-group in which the experimental intervention seemed to be beneficial, may imply that the nutritional support offered may have been inadequate in composition, duration or timing.

The strength of the present trial is that it was randomised, and that the overall loss to follow-up was modest. Although the planned sample size was not achieved due to slow recruitment pace, the study was large enough to detect clinically important differences with high power. In addition, our outcome measures included a functional outcome, i.e. handgrip strength, which is an important marker of health status including survival ${ }^{(35)}$. However, we only used proxies in assessing body composition and did not have markers of energy intake or expenditure and in most of our patients, compliance was assessed using reported information. Future studies should use better methods and include mechanistic sub-studies in order to be able to fully explain the findings.

\section{Conclusions}

Among $\mathrm{PTB}+\mathrm{HIV-cO-infected} \mathrm{patients,} \mathrm{energy-protein}$ supplementation against a background of high multimicronutrient intake had no overall effect on weight and body composition, but had a marginally significant effect on handgrip strength at 5 months. More studies are needed to develop a macronutrient supplement for TB patients $\mathrm{CO}^{-}$ infected with HIV, with effects on lean mass, functional outcomes and survival, before it can be recommended to TB programmes.

\section{Acknowledgements}

The present study was supported by the Danish Council for Independent Research - Medical Sciences (grant no. 2204-0404) by Danida through the Consultative Research Committee for Development Research (104.Dan.8-898) and the University of Copenhagen through the Cluster in International Health. The funding bodies had no role in the study design, data collection, data analysis, data interpretation or decision to publish the findings. H. F., N. R., J. C. and A. B. A. conceived the study. G. P. and K. J. coordinated the implementation of the study, and G. P. analysed the data and wrote the first draft of the manuscript. All authors contributed to the data collection and interpretation of the results and commented on the drafts and approved the final version. All authors reported no conflicts of interests. The authors would also like to thank all the health facility staff as well as all study participants who were involved in the study. 


\section{References}

1. World Health Organization (2010) WHO Report 2010: Global Tuberculosis Control. Geneva: WHO.

2. Woldehanna S \& Volmink J (2004) Treatment of latent tuberculosis infection in HIV infected persons. Cochrane Database Systematic Review, issue 1, CD000171. http://dx. doi.org/10.1002/14651858.CD000171.pub2 (accessed June 2010).

3. Corbett EL, Watt CJ, Walker N, et al. (2003) The growing burden of tuberculosis: global trends and interactions with the HIV epidemic. Arch Intern Med 163, 1009-1021.

4. Range N, Magnussen P, Mugomela A, et al. (2007) HIV and parasitic co-infections in tuberculosis patients: a crosssectional study in Mwanza, Tanzania. Ann Trop Med Parasitol 101, 343-351.

5. Onwubalili JK (1988) Malnutrition among tuberculosis patients in Harrow, England. Eur J Clin Nutr 42, 363-366.

6. Macallan DC, Noble C, Baldwin C, et al. (1995) Energy expenditure and wasting in human immunodeficiency virus infection. $N$ Engl J Med 333, 83-88.

7. Macallan DC (1999) Malnutrition in tuberculosis. Diagn Microbiol Infect Dis 34, 153-157.

8. Niyongabo T, Henzel D, Idi M, et al. (1999) Tuberculosis, human immunodeficiency virus infection, and malnutrition in Burundi. Nutrition 15, 289-293.

9. van Lettow M, Harries AD, Kumwenda JJ, et al. (2004) Micronutrient malnutrition and wasting in adults with pulmonary tuberculosis with and without HIV co-infection in Malawi. BMC Infect Dis $\mathbf{4}, 61$.

10. Swaminathan S, Padmapriyadarsini C, Sukumar B, et al. (2008) Nutritional status of persons with HIV infection, persons with HIV infection and tuberculosis, and HIV-negative individuals from southern India. Clin Infect Dis 46, 946-949.

11. Paton NI, Castello-Branco LR, Jennings G, et al. (1999) Impact of tuberculosis on the body composition of HIVinfected men in Brazil. J Acquir Immune Defic Syndr Hum Retrovirol 20, 265-271.

12. Range N, Changalucha J, Krarup H, et al. (2006) The effect of multi-vitamin/mineral supplementation on mortality during treatment of pulmonary tuberculosis: a randomised two-by-two factorial trial in Mwanza, Tanzania. Br J Nutr 95, 762-770.

13. Abba K, Sudarsanam TD, Grobler L, et al. (2008) Nutritional supplements for people being treated for active tuberculosis. Cochrane Database Systematic Reviews, issue 4, CD006086. http://www2.cochrane.org/reviews/en/ ab006086.html (accessed June 2010).

14. PrayGod G, Range N, Faurholt-Jepsen D, et al. (2011) Daily multi-micronutrient supplementation during tuberculosis treatment increases weight and grip strength among HIV uninfected but not HIV infected patients in Mwanza, Tanzania. J Nutr 141, 685-691.

15. Chonde TM, Basra D, Mfinanga SG, et al. (2010) National anti-tuberculosis drug resistance study in Tanzania. Int J Tuberc Lung Dis 14, 967-972.

16. Ministry of Health and Social Welfare (2003) Manual of the National Tuberculosis and Leprosy Programme in Tanzania, 4th ed. Dar es Salaam: Ministry of Health and Social Welfare.

17. World Health Organization (2003) Treatment of Tuberculosis: Guidelines for National Programmes. Geneva: WHO.

18. Githui W, Kitui F, Juma ES, et al. (1993) A comparative study on the reliability of the fluorescence microscopy and
Ziehl-Neelsen method in the diagnosis of pulmonary tuberculosis. East Afr Med J 70, 263-266.

19. Ministry of Health and Social Welfare (2006) Manual of the National Tuberculosis and Leprosy Programme in Tanzania, 5th ed. Dar es Salaam: Ministry of Health and Social Welfare.

20. Ministry of Health and Social Welfare (2005) National Guidelines for the Clinical Management of HIV and AIDS. Dar es Salaam: Ministry of Health and Social Welfare.

21. Institute of Medicine (2005) Dietary Reference Intakes for Energy, Carbohydrate, Fiber, Fat, Fatty Acids, Cholesterol, Protein, and Amino Acids (Macronutrients), pp. 1-28. Washington, DC: National Academy Press.

22. PrayGod G, Range N, Faurholt-Jepsen D, et al. (2011) Weight, body composition and handgrip strength among pulmonary tuberculosis patients: a matched cross-sectional study in Mwanza, Tanzania. Trans $R$ Soc Trop Med Hyg 105, 140-147.

23. Frisancho AR (1990) Anthropometric Standards for the Evaluation of Growth and Nutritional Status. Ann Arbor, MI: University of Michigan Press.

24. Paton NI, Chua YK, Earnest A, et al. (2004) Randomized controlled trial of nutritional supplementation in patients with newly diagnosed tuberculosis and wasting. Am J Clin Nutr 80, $460-465$.

25. Kotler DP, Wang J \& Pierson RN (1985) Body composition studies in patients with the acquired immunodeficiency syndrome. Am J Clin Nutr 42, 1255-1265.

26. Macallan DC, McNurlan MA, Milne E, et al. (1995) Wholebody protein turnover from leucine kinetics and the response to nutrition in human immunodeficiency virus infection. Am J Clin Nutr 61, 818-826.

27. Paton NI, Ng YM, Chee CB, et al. (2003) Effects of tuberculosis and HIV infection on whole-body protein metabolism during feeding, measured by the [15N]glycine method. Am J Clin Nutr 78, 319-325.

28. Selberg O, Suttmann U, Melzer A, et al. (1995) Effect of increased protein intake and nutritional status on wholebody protein metabolism of AIDS patients with weight loss. Metab Clin Exp 44, 1159-1165.

29. Williams SB, Bartsch G, Muurahainen N, et al. (2003) Protein intake is positively associated with body cell mass in weightstable HIV-infected men. J Nutr 133, 1143-1146.

30. Golden MH \& Golden BE (1981) Effect of zinc supplementation on the dietary intake, rate of weight gain, and energy cost of tissue deposition in children recovering from severe malnutrition. Am J Clin Nutr 34, 900-908.

31. Golden MHN (1992) Nutritional deficiency as a cause of growth failure. In Human Growth: Basic and Clinical Aspects, pp. 175-182 [M Hernandez and J Argente, editors]. Amsterdam: Elsevier Science Publishers B.V.

32. Aviram G, Fishman J \& Boiselle P (2003) Thoracic manifestations of AIDS. Appl Radiol 32, 11-21.

33. Macallan DC, Noble C, Baldwin C, et al. (1993) Prospective analysis of patterns of weight change in stage IV human immunodeficiency virus infection. Am J Clin Nutr $\mathbf{5 8}$ 417-424

34. Range NS, Malenganisho W, Temu MM, et al. (2010) Body composition of HIV-positive patients with pulmonary tuberculosis: a cross-sectional study in Mwanza, Tanzania. Ann Trop Med Parasitol 104, 81-90.

35. Cooper R, Kuh D \& Hardy R (2010) Objectively measured physical capability levels and mortality: systematic review and meta-analysis. BMJ 341, c4467. 